\title{
Climate variability and extreme drought in the upper Solimões River (western Amazon Basin): Understanding the exceptional 2010 drought
}

\author{
Jhan Carlo Espinoza, ${ }^{1,2}$ Josyane Ronchail, ${ }^{3}$ Jean Loup Guyot, ${ }^{4,5}$ Clementine Junquas, ${ }^{6}$ \\ Philippe Vauchel, ${ }^{4,7}$ Waldo Lavado, ${ }^{2,8}$ Guillaume Drapeau, ${ }^{3,9}$ and Rodrigo Pombosa ${ }^{10}$ \\ Received 19 April 2011; revised 25 May 2011; accepted 26 May 2011; published 12 July 2011.
}

[1] This work provides an initial overview of climate features and their related hydrological impacts during the recent extreme droughts $(1995,1998,2005$ and 2010) in the upper Solimões River (western Amazon), using comprehensive in situ discharge and rainfall datasets. The droughts are generally associated with positive SST anomalies in the tropical North Atlantic and weak trade winds and water vapor transport toward the upper Solimões, which, in association with increased subsidence over central and southern Amazon, explain the lack of rainfall and very low discharge values. But in 1998, toward the end of the 1997-98 El Niño event, the drought is more likely related to an anomalous divergence of water vapor in the western Amazon that is characteristic of a warm event in the Pacific. During the austral spring and winter of 2010 , the most severe drought since the seventies has been registered in the upper Solimões. Its intensity and its length, when compared to the 2005 drought, can be explained by the addition of an El Niño in austral summer and a very warm episode in the Atlantic in boreal spring and summer. As in 2005, the lack of water in 2010 was more important in the southern tropical tributaries of the upper Solimões than in the northern ones. Citation: Espinoza, J. C., J. Ronchail, J. L. Guyot, C. Junquas, P. Vauchel, W. Lavado, G. Drapeau, and R. Pombosa (2011), Climate variability and extreme drought in the upper Solimões River (western Amazon Basin): Understanding the exceptional 2010 drought, Geophys. Res. Lett., 38, L13406, doi:10.1029/2011GL047862.

\section{Introduction}

[2] Extreme hydrological events have been increasing since the end of the 1980s in the Amazon River [Espinoza

\footnotetext{
${ }^{1}$ Instituto Geofísico del Perú, Lima, Peru.

${ }^{2}$ Facultad de Ingeniería Agrícola, Universidad Agraria La Molina, Lima, Peru.

${ }^{3}$ Laboratoire d'Océanographie et de Climat: Expérimentation et Approches Numériques, Université Paris Diderot, Sorbonne Paris Cité, Paris, France.

${ }^{4}$ Géosciences Environnement Toulouse, Toulouse, France.

${ }^{5}$ Institut de Recherche pour le Développement, Brasilia, Brazil.

${ }^{6}$ Centro de Investigaciones del Mar y la Atmosfera, Buenos Aires, Argentina.

${ }^{7}$ Institut de Recherche pour le Développement, Lima, Peru.

${ }^{8}$ Servicio Nacional de Meteorología e Hidrología, Lima, Peru.

${ }^{9}$ Pôle de Recherche pour l'Organisation et la Diffusion de l'Information Géographique, Paris, France.

${ }^{10}$ Instituto Nacional de Meteorología e Hidrología, Quito, Ecuador.
}

Copyright 2011 by the American Geophysical Union. 0094-8276/11/2011GL047862 et al., 2009b]. They cause inundations, as in 1999, 2006 and 2009 , or very low water stages, as in 1998, 2005 and 2010, which are harmful to people living nearby the watercourse and damaging for agriculture and ecosystems [e.g., Saleska et al., 2007; Phillips et al., 2009; Asner and Alencar, 2010; Lewis et al., 2011; Xu et al., 2011]. While interannual rainfall and discharge variability are related to the El Niño Southern Oscillation (ENSO) in the northeastern Amazon [e.g., Marengo et al., 1998; Uvo et al., 1998; Williams et al., 2005], no clear ENSO impact is documented in the western part of the basin [Ronchail et al., 2002; Poveda et al., 2006; Espinoza et al., 2009a, 2009b]. However, high Tropical North Atlantic (TNA) SST, which are associated with an anomalous northward position of ITCZ, cause dry conditions in the southern and western Amazon [Marengo, 1992; Uvo et al., 2000], which are particularly severe during austral winter and spring [Ronchail et al., 2002; Espinoza et al., 2009b; Yoon and Zeng, 2010]. For instance, the dramatic 2005 drought, which was particularly intense in the southwestern Amazon, has been attributed to warm SST over TNA [Zeng et al., 2008; Marengo et al., 2008; Cox et al., 2008].

[3] In this study, we aim to document the recent droughts in the Peruvian Solimões basin and their relationship with atmospheric circulation, paying special attention to the recent 2010 drought. The upper Solimões River has a huge drainage $\left(750,000 \mathrm{~km}^{2}\right)$ half of which is in the Andes, above $500 \mathrm{~m}$ (Figure 1a). The long term mean discharge at Tamshiyacu (the most upstream gauging station on the Solimões River, Figure 1a) is $32000 \mathrm{~m}^{3} / \mathrm{s}$, about $16 \%$ of the Amazon discharge at the estuary [Espinoza et al., 2006, 2009b]. Moreover, when analyzing mean annual rainfall and discharge at Tamshiyacu station, a negative trend was documented in both variables for the 1970-2004 period and frequent droughts have been observed since the end of the 1980s [Espinoza et al., 2009b]. Among them, the 2010 drought was particularly severe and it led the authorities to declare a state of public calamity in the Peruvian Amazon due to problems in fluvial transport and food supply to population (SENAMHI-Peru press release $\mathrm{N}^{\circ} 076-2010$ ). Finally, it is particularly relevant to focus on this region of the Amazon as it is still poorly documented in terms of climate and hydrology.

\section{Data Description}

[4] Mean monthly river discharge data are available in seven gauging stations located in the Peruvian Amazon, most of them during the 1989-2009 period. In Tamshiyacu station (Figure 1a), discharge values are extended to the 1970 2010 period using their correlation with the water level 


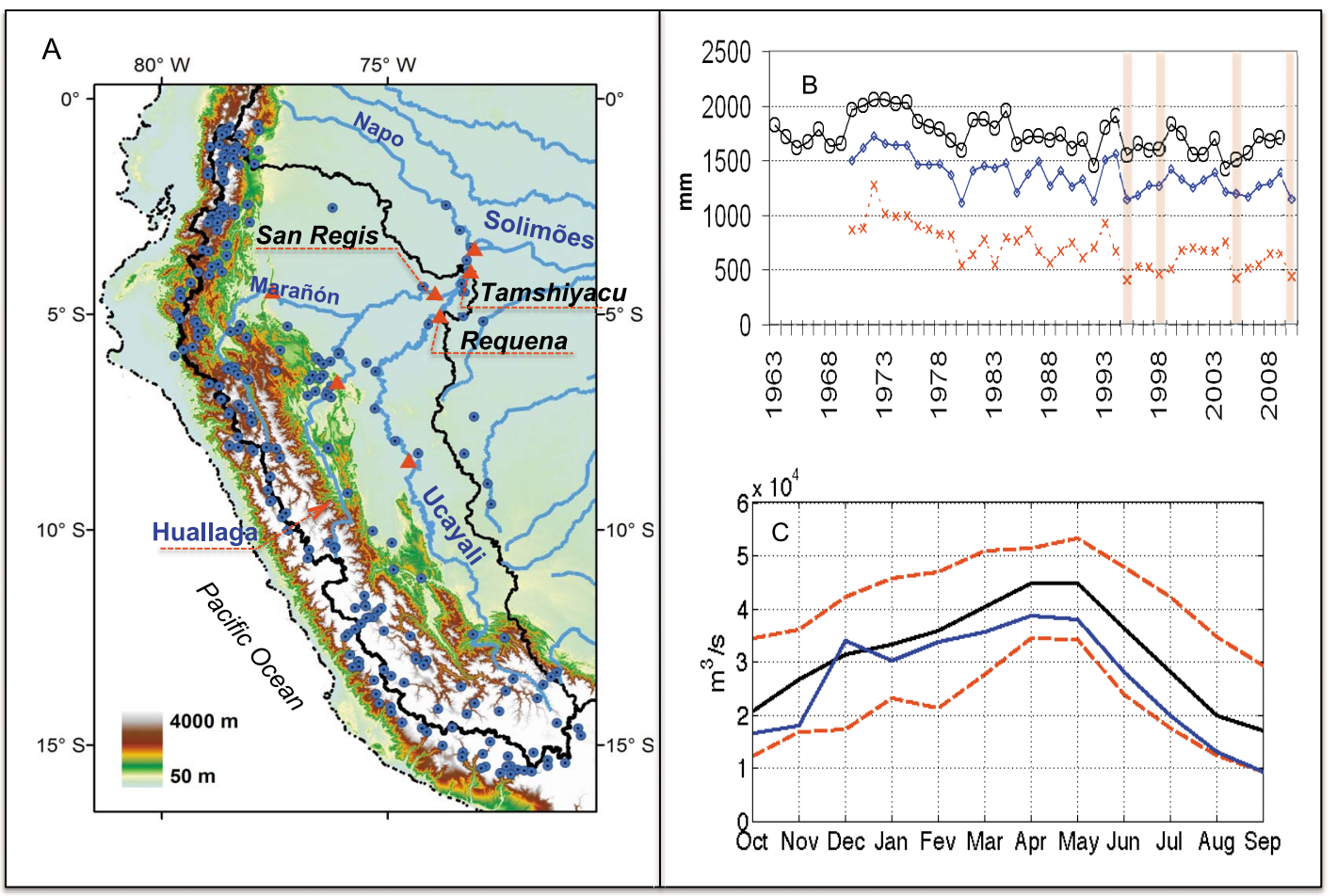

Figure 1. (a) Hydrological and rainfall stations used in this study are represented by red triangles and blue circles, respectively. The names of the main rivers are indicated. (b) Interannual variability (1963-2010) of annual rainfall (black line), annual runoff (blue line) and minimum runoff (red line) at Tamshiyacu station. The red vertical lines show the extreme drought years analyzed in this study. (c) Mean (1970-2010) hydrological cycle at Tamshiyacu station (black line). The red dashed lines represent the maximum and minimum discharge values. The blue line represents the 2010 discharge.

data measured in the nearby Iquitos hydrometric station [Espinoza et al., 2006]. Requena on the Ucayali River and San Regis on the Marañón River, which permit analysis of the southern and northern rivers contributions (Figure 1a), have short time series for the 1997-2010 and 1999-2010 periods, respectively. For more details about the stations and their annual cycle, see auxiliary material and Figure S3. ${ }^{1}$ Observed rainfall data are available at monthly time steps for 234 stations for the 1963-2008 period (Figure 1a) [Espinoza et al., 2009a].

[5] Climate variability is analyzed using the global monthly SST data [Reynolds and Smith, 1994], which comes from the CPC-NOAA. We also examine the $2.5 \times 2.5$ degree resolution horizontal and vertical winds, geopotential high and humidity data from NCEP-NCAR reanalysis [Kalnay et al., 1996] to describe the atmosphere characteristics during the driest episodes of the 1970-2010 period. These data were obtained from the NOAA data server. The vertically integrated water vapor flux is derived from the specific humidity and the horizontal wind between the ground and $300 \mathrm{hPa}$ [Peixoto and Oort, 1992].

\section{Hydrological Impacts During the Extreme Droughts}

[6] Interannual variability of total rainfall, mean and lowflow runoff at Tamshiyacu station are displayed in Figure $1 \mathrm{~b}$.

\footnotetext{
${ }^{1}$ Auxiliary materials are available in the HTML. doi:10.1029/ 2011GL047862.
}

The selected extreme drought events are characterized by monthly low flow runoff below the tenth percentile $\left(\sim 500 \mathrm{~mm}\right.$ or $\left.\sim 12000 \mathrm{~m}^{3} / \mathrm{s}\right)$. They occurred in 1995,1998 , 2005 and 2010, which happen to be transition years between El Niño (EN) and La Niña events (LN) of different strengths, with the exception of 2005. During these years, mean rainfall in the Tamshiyacu basin was generally below normal in January-February, except in 1997-98, and, later on, from April or June to August (Figures 2b, 2d and 2f). In 2010 , the rainfall deficit was already observed in OctoberNovember, and it became very strong during the autumn and winter, as shown by the observations (Figure S1) and by TRMM rainfall data [Lewis et al., 2011]. As a consequence, the Solimões discharge at Tamshiyacu is regularly low from January or February (October in 2010) to September (Figures 2a, 2e, and 1c), with the exception of 1998 when the discharge deficit only began in June (Figure 2c).

[7] Comparing the two most severe droughts, we note that in 2005, below normal discharge was reported since February in both the southern and northern tributaries of the upper Solimões (Figures 2g and 2h). In 2010, the discharge deficit was important since March in the northern Marañon River at San Regis, but the lowest observed values in this station were not reached (Figure 2k). In the southern Ucayali River at Requena, the discharge deficit was already observed in October-November and it was close to the lowest multiannual values from January to August (Figure 2j). In the station of Tamshiyacu, the discharge of which combines the southern and northern rivers contributions, both the 2005 and 2010 droughts seem to be comparable, with weak 




Figure 2. Maximum (upper red dashed lines), mean (black lines) and minimum (bottom red dashed lines) monthly discharge values (1970-2010 mean) and 1995, 1998 and 2005 values at Tamshiyacu (blue lines) (Figures 2a, 2c and 2e respectively). Mean monthly rainfall at Tamshiyacu (black line, 1963-2009 period) and 1995, 1998 and 2005 monthly rainfall (Figures 2b, 2d and $2 \mathrm{f}$ respectively). Maximum (upper red dashed lines), mean (black lines) and minimum (bottom red dashed lines) monthly discharge values (1970-2010 mean) and annual values (blue lines) at Requena, San Regis and Tamshiyacu in 2005 (Figures 2g, 2h and 2i respectively) and 2010 (Figures 2j, 2k and 21 respectively). 
negative anomalies in summer (with the exception of November-December in 2005, December in 2010) and autumn and very low values from May to September (Figures 2i and 21). On the 5th of September 2010, the discharge of the upper Solimões at Tamshiyacu station was estimated at $8300 \mathrm{~m}^{3} / \mathrm{s}$ which represents $-51 \%$ of the historical September mean discharge; this is the lowest value registered in the Solimões River since 1970.

\section{Climate Features During the Extreme Droughts}

[8] Since dry conditions are often observed in austral summer before the droughts, we shall principally show results of our analysis of the ocean and atmosphere patterns during the April-August period, which corresponds to the rainfall recession period and to the annual low flow period in the upper Solimões (Figure 2).

[9] The different drought events have some specific features in common. SST is higher than normal in the tropical and mid-latitude regions of northern Atlantic (Figures 3a, $3 \mathrm{~d}, 3 \mathrm{~g}$, and $3 \mathrm{j}$ ). The mean April-August SST over the tropical north Atlantic $\left(0-30^{\circ} \mathrm{N}\right.$ and $\left.20-60^{\circ} \mathrm{W}\right)$ was especially strong in 2010 , surpassing $24.5^{\circ}$ and reaching $26^{\circ}$ in September (Figure $3 \mathrm{~m}$ ). It is remarkable that SST in this region has been increasing during the study period (Figure $3 \mathrm{~m}$ ) and that the Atlantic Multidecadal Oscillation (AMO) index, a mode of multidecadal variability of northern Atlantic surface temperatures, entered a warm phase in the 1990s [Knight et al., 2005]. Some particular SST features are noticeable: in 1995, the warm SST anomalies were more pronounced in the eastern subtropical Atlantic, off the African and Spanish coasts (Figure 3a) and in 1998 they were relatively weak in the tropical and subtropical Atlantic (Figure 3d). Warm temperatures were also observed in the southern tropical and subtropical Atlantic but the anomalies were less accentuated than in the northern part of this ocean. In the Pacific Ocean, there is no systematic anomaly. In April-August 1998 moderate positive SST anomalies $\left(+2^{\circ} \mathrm{C}\right)$ in the eastern equatorial Pacific characterized the ending of the strong 1997-98 EN (Figure 3d), distinguished by positive anomalies as high as $+4^{\circ} \mathrm{C}$ at the peak of the event (December-January-February). In April-August 1995 and 2010, negative SST anomalies appeared in the eastern Pacific, featuring the outbreak of the 1995-96 and 2010-11 LN that followed the 1994-95 and 2009-10 EN (Figures 3a and $3 \mathrm{j}$ ).

[10] The geopotential height at $850 \mathrm{hPa}$ is characterized by significant anomalies in the northern Atlantic. Generally, below normal heights $(<20 \mathrm{~m})$ are observed over the western subtropical and mid-latitude Atlantic (Figures 3b, 3e, 3h, and $3 \mathrm{k}$ ), associated with ascent anomalies, as demonstrated by a composite of the vertical wind anomaly (Figure S2c) and increasing rainfall. Over the equatorial Atlantic, weak positive geopotential height anomalies prevail, except in 1995. In the Pacific, the geopotential height anomalies change from one event to another; they were positive in the equatorial Pacific in 1998 and 2010, at the end of the 199798 and 2009-10 EN and they were very weak in 1995 and 2005 (Figures 3b, 3e, 3h and 3k). In association with the low-pressure in the northwestern Atlantic, convergence, ascendance and convection are accentuated and rainfall is higher than normal in this region (Figure S2a).
[11] The reduced Subtropical High and the increased geopotential height over the equatorial Atlantic are consistent with the slowdown of the trade winds (Figure S2b), a decreased water vapor transport over the Atlantic and northern South America and an increase in water vapor flux divergence over western Amazon especially over the Peruvian Amazon basin in 2010 (Figures 3c, 3f, 3i, and 31). From April to August (1970-2009), the mean meridional humidity flux between $0^{\circ}$ to $15^{\circ} \mathrm{S}$ at $75^{\circ} \mathrm{W}$ and the average SST in the $20^{\circ}-60^{\circ} \mathrm{W}$ and $30^{\circ} \mathrm{N}-0^{\circ}$ region are significantly correlated $(\mathrm{r}=0.68 ; \mathrm{p} \leq 0.001)$. During warm events in the TNA, the deficit of water vapor transport at $75^{\circ} \mathrm{W}$ and between $0^{\circ} \mathrm{N}$ and $15^{\circ} \mathrm{S}$ is as low as $-56 \%$ in $2010,-29 \%$ in $2005,-14 \%$ in 1998 and $-20 \%$ in 1995 (Figures $3 \mathrm{~m}$ and $3 \mathrm{n})$. The deficit of water vapor transport, the divergence and the enhanced subsidence (Figure S2c) contribute to reduced rainfall over the upper Solimões (Figures 2, S1, and S2a). On the contrary, the eastward water vapor anomaly tends to maintain water vapor over the ocean and northern South America around $10^{\circ} \mathrm{N}$. That anomaly, combined with the enhanced ascent (Figure S2c), favors rainfall over northern South America (Figure S2a). In 1998, an anomalous and intense moist flux divergence was observed in the western Amazon (Figure 3f), consistent with the EN that produces abundant low-level jet episodes [e.g., Marengo et al., 2004].

[12] Details about the 2010 event show that during October 2009-March 2010, positive SST anomalies over the equatorial Pacific $\left(>2^{\circ} \mathrm{C}\right)$ were predominant (Figures S4a and S4b), corresponding to the 2009-10 EN. A typical southeastward moisture transport was observed in OctoberDecember in the central and southern part of the Peruvian Amazon, taking away water vapor out of the basin and favoring early drier than usual conditions in Tamshiyacu (Figure 1c). The SST were near normal in the equatorial Pacific during April-June and they became negative in winter at the beginning of the 2010-2011 LN (Figure S4d). As mentioned before, the northern Atlantic SST were particularly high since the boreal winter and the SST anomalies encompassed wide regions in the tropical Atlantic and North of $40^{\circ} \mathrm{N}$ (Figures $3 \mathrm{~g}$ and $3 \mathrm{j}$ ). The occurrence of an EN in 2009-10 is a notable difference in comparison with the 2005 drought when no SST anomaly was observed in the Equatorial Pacific [Marengo et al., 2008]. It seems that, whereas 1998 experienced a strong EN and 2005 a warm north Atlantic event, both these types of warm episodes afflicted the end of 2009 and 2010, combining their hydrological consequences.

\section{Concluding Remarks}

[13] Four intense and recent droughts (1995, 1998, 2005 and 2010) produced the weakest low-flow discharges of the last forty years in the upper Solimões River, the headwaters of the Amazon basin. In 1995, 2005 and 2010, these droughts were associated with higher than normal SST in the northern Atlantic in April-August, with the slowdown of the trade winds and reduced water vapor transport toward the western Amazon basin. Consequently, rainfall was lower than usual and extreme low-stage discharge was observed in the upper Solimões, especially in the southern tributaries close to a center of increased divergence and subsidence. 


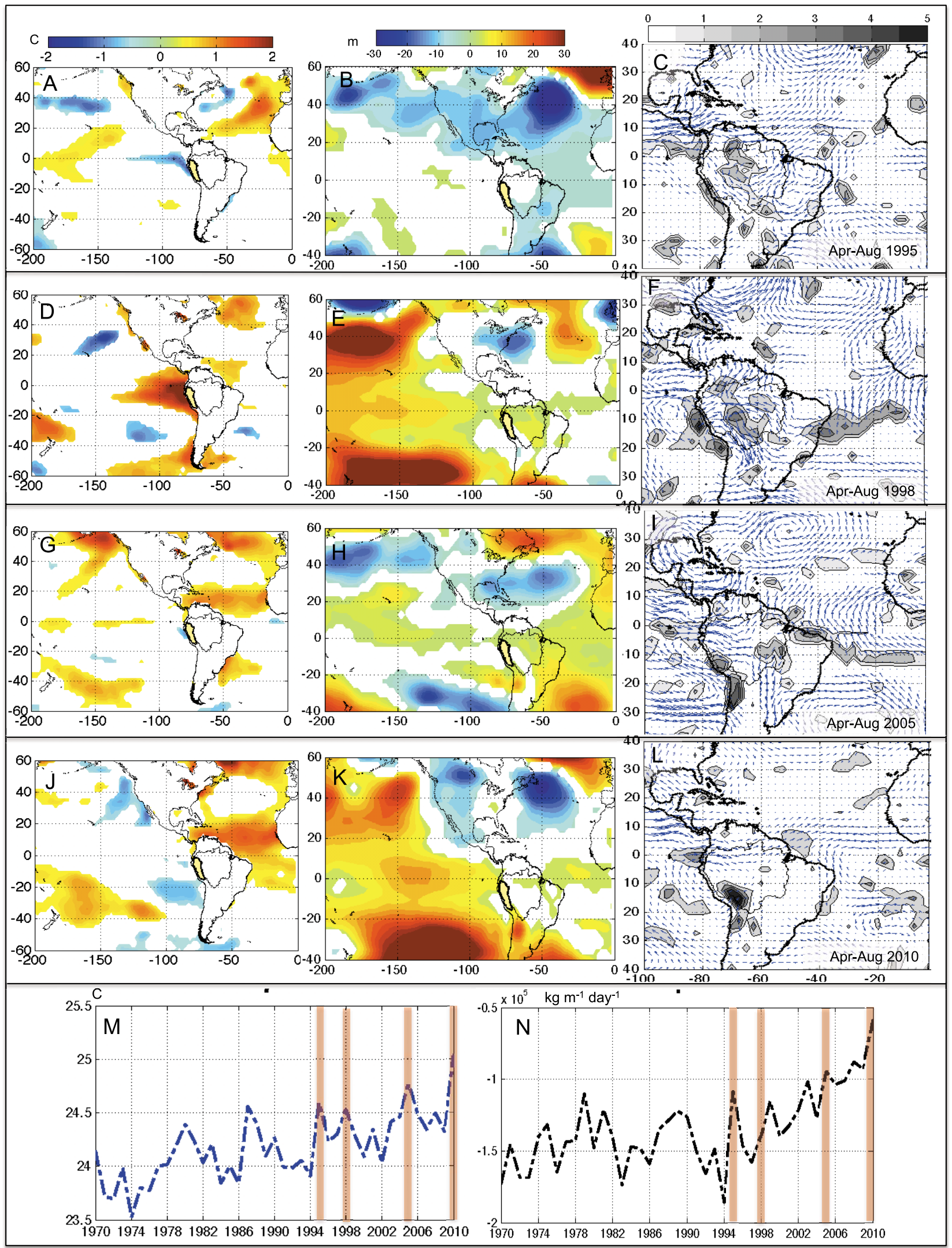

Figure 3. April to August mean SST $\left({ }^{\circ} \mathrm{C}\right.$, left), $850 \mathrm{hPa}$ geopotential height (m, centre) and vertically integrated water vapor flux anomalies (vectors, $\mathrm{kg} \mathrm{m}^{-1} \mathrm{day}^{-1}$ ) and positive divergence standardized values (contours, without unit) between the ground and $300 \mathrm{hPa}$ (right) in (a-c) 1995, (d-f) 1998, (g-i) 2005, and in (j-1) 2010. Only values higher than $1 \times$ standard deviation are plotted $\left(2 \times\right.$ standard deviation for SST data). (m) Mean April-August SST in the $20^{\circ}-60^{\circ} \mathrm{W}$ and $0^{\circ}-30^{\circ} \mathrm{N}$ region and (n) mean April-August meridional water vapor flux between $0^{\circ}$ and $15^{\circ} \mathrm{S}$ at $75^{\circ} \mathrm{W}$. 
[14] During the 1998 El Niño, the reduced water vapor in April-August was caused by an anomalous divergence over the western Amazon. The intensity and length of the 2010 drought, when compared to the former ones, can be related to the successive occurrences of a moderate El Niño in austral summer, and a very warm tropical north Atlantic in the boreal spring and summer. The 2010 drought has also been dramatic in the northwestern Brazilian Amazon as recently reported by $X u$ et al. [2011] about the water levels of the Manaus station.

[15] Acknowledgments. We are grateful to Jorge Carranza, Pascal Fraizy, Marcos Villacís, and Karena Quiroz who helped collecting data and to Katherine W. Dunbar, Léa Thalmard, and the two anonymous reviewers for their contribution to improve this paper.

[16] The Editor thanks two anonymous reviewers for their assistance evaluating this manuscript.

\section{References}

Asner, G. P., and N. Alencar (2010), Drought impacts on the Amazon forest: The remote sensing perspective, New Phytol., 187, 569-578, doi:10.1111/j.1469-8137.2010.03310.x.

Cox, P. M., et al. (2008), Increasing risk of Amazonian drought due to decreasing aerosol pollution, Nature, 453, 212-215, doi:10.1038/ nature 06960.

Espinoza, J. C., P. Fraizy, J.-L. Guyot, J. Ordoñez, R. Pombosa, and J. Ronchail (2006), La variabilité des débits du rio Amazonas au Pérou, in Climate Variability and Change: Hydrological Impacts, IAHS Publ., 308, 424-429.

Espinoza, J. C., et al. (2009a), Spatio-temporal rainfall variability in the Amazon Basin countries (Brazil, Peru, Bolivia, Colombia and Ecuador), Int. J. Climatol., 29, 1574-1594, doi:10.1002/joc.1791.

Espinoza, J. C., et al. (2009b), Contrasting regional discharge evolutions in the Amazon basin (1974-2004), J. Hydrol., 375, 297-311, doi:10.1016/ j.jhydrol.2009.03.004

Kalnay, E., et al. (1996), The NCEP/NCAR 40-year reanalysis project, Bull. Am. Meteorol. Soc., 77(3), 437-471, doi:10.1175/1520-0477 (1996) $077<0437$ :TNYRP $>2.0$. CO;2.

Knight, J. R., R. J. Allan, C. K. Folland, M. Vellinga, and M. E. Mann (2005), A signature of persistent natural thermohaline circulation cycles in observed climate, Geophys. Res. Lett., 32, L20708, doi:10.1029/ 2005GL024233.

Lewis, S. L., P. M. Brando, O. L. Phillips, G. M. F. van der Heijden, and D. Nepstad (2011), The 2010 Amazon drought, Science., 311, 554, doi: $10.1126 /$ science. 1200807 .

Marengo, J. (1992), Interannual variability of surface climate in the Amazon basin, Int. J. Climatol., 12, 853-863, doi:10.1002/joc.3370120808.

Marengo, J., J. Tomasella, and C. Uvo (1998), Long-term stream flow and rainfall fluctuation in tropical South America: Amazonia, eastern Brazil, and northwest Peru, J. Geophys. Res., 103, 1775-1783, doi:10.1029/ 97JD02551.

Marengo, J., W. R. Soares, C. Saulo, and M. Nicolini (2004), Climatology of the low-level jet east of the Andes as derived from the NCEP reana- lyzes, J. Clim., 17, 2261-2280, doi:10.1175/1520-0442(2004)017<2261: COTLJE $>2.0 . \mathrm{CO} ; 2$.

Marengo, J., et al. (2008), The drought in Amazonia in 2005, J. Clim., 21, 495-516, doi:10.1175/2007JCLI1600.1.

Peixoto, J. P., and A. H. Oort (1992), Physics of Climate, 520 pp., Am. Inst. of Phys., New York.

Phillips, O. L., et al. (2009), Drought sensitivity of the Amazon rainforest, Science, 323, 1344-1347, doi:10.1126/science.1164033.

Poveda, G., P. R. Waylen, and R. S. Pulwarty (2006), Annual and interannual variability of the present climate in northern South America and southern Mesoamerica, Palaeogeogr. Palaeoclimatol. Palaeoecol., 234, 3-27, doi:10.1016/j.palaeo.2005.10.031.

Reynolds, R. W., and T. M. Smith (1994), Improved global sea surface temperature analyses using optimum interpolation, J. Clim., 7, 929-948, doi:10.1175/1520-0442(1994)007<0929:IGSSTA $>2.0 . C O ; 2$

Ronchail, J., et al. (2002), Rainfall variability in the Amazon Basin and SSTs in the tropical Pacific and Atlantic oceans, Int. J. Climatol., 22, 1663-1686, doi: $10.1002 /$ joc. 815

Saleska, S. R., K. Didan, A. R. Huete, and H. R. da Rocha (2007), Amazon forests green-up during 2005 drought, Science, 318, 612, doi:10.1126/ science. 1146663

Uvo, C., C. Repelli, S. Zebiak, and Y. Kushnir (1998), The relationship between tropical pacific and atlantic SST and northeast Brazil monthly precipitation, J. Clim., 11, 551-562, doi:10.1175/1520-0442(1998) $011<0551$ :TRBTPA $>2.0 . \mathrm{CO} ; 2$

Uvo, C., U. Tolle, and R. Berndtsson (2000), Forecasting discharge in Amazon using artificial neural networks, Int. J. Climatol., 20 , 1495-1507, doi:10.1002/1097-0088(200010)20:12<1495::AIDJOC549>3.0.CO;2-F.

Williams, E., et al. (2005), The drought of the century in the Amazon basin: An analysis of the regional variation of rainfall in South America in 1926, Acta Amazon., 35(2), 231-238, doi:10.1590/S004459672005000200013

Xu, L., A. Samanta, M. Costa, S. Ganguly, R. Nemani, and R. Myneni (2011), Widespread decline in greenness of Amazonian vegetation due to the 2010 drought, Geophys. Res. Lett., 38, L07402, doi:10.1029/ 2011 GL046824.

Yoon, J. H., and H. Zeng (2010), An Atlantic influence on Amazon rainfall, Clim. Dyn., 34, 249-264, doi:10.1007/s00382-009-0551-6.

Zeng, N., et al. (2008), Causes and impact of the 2005 Amazon drought, Environ. Res. Lett., 3, 014002, doi:10.1088/1748-9326/3/1/014002.

G. Drapeau and J. Ronchail, Laboratoire d'Océanographie et de Climat: Expérimentation et Approches Numériques, Université Paris Diderot, Sorbonne Paris Cité, Paris F-75005, France.

J. C. Espinoza, Instituto Geofísico del Perú, Calle Badajoz 169 IV Etapa, Mayorazgo, Ate. Lima 03, Perú. (Jhan-carlo.espinoza@igp.gob.pe)

J. L. Guyot and Philippe Vauchel, Géosciences Environnement Toulouse, Toulouse F-31400, France.

C. Junquas, Centro de Investigaciones del Mar y la Atmosfera, Buenos Aires 1428, Argentina.

W. Lavado, Servicio Nacional de Meteorología e Hidrología, Jr. Cahuide 785 Jesús María, Lima 11, Peru.

R. Pombosa, Instituto Nacional de Meteorología e Hidrología, Iñaquito 700 y Correa, Quito, Ecuador. 